\title{
Justin TumilaAR
}

\section{SCRAPHEAD SHAPES}

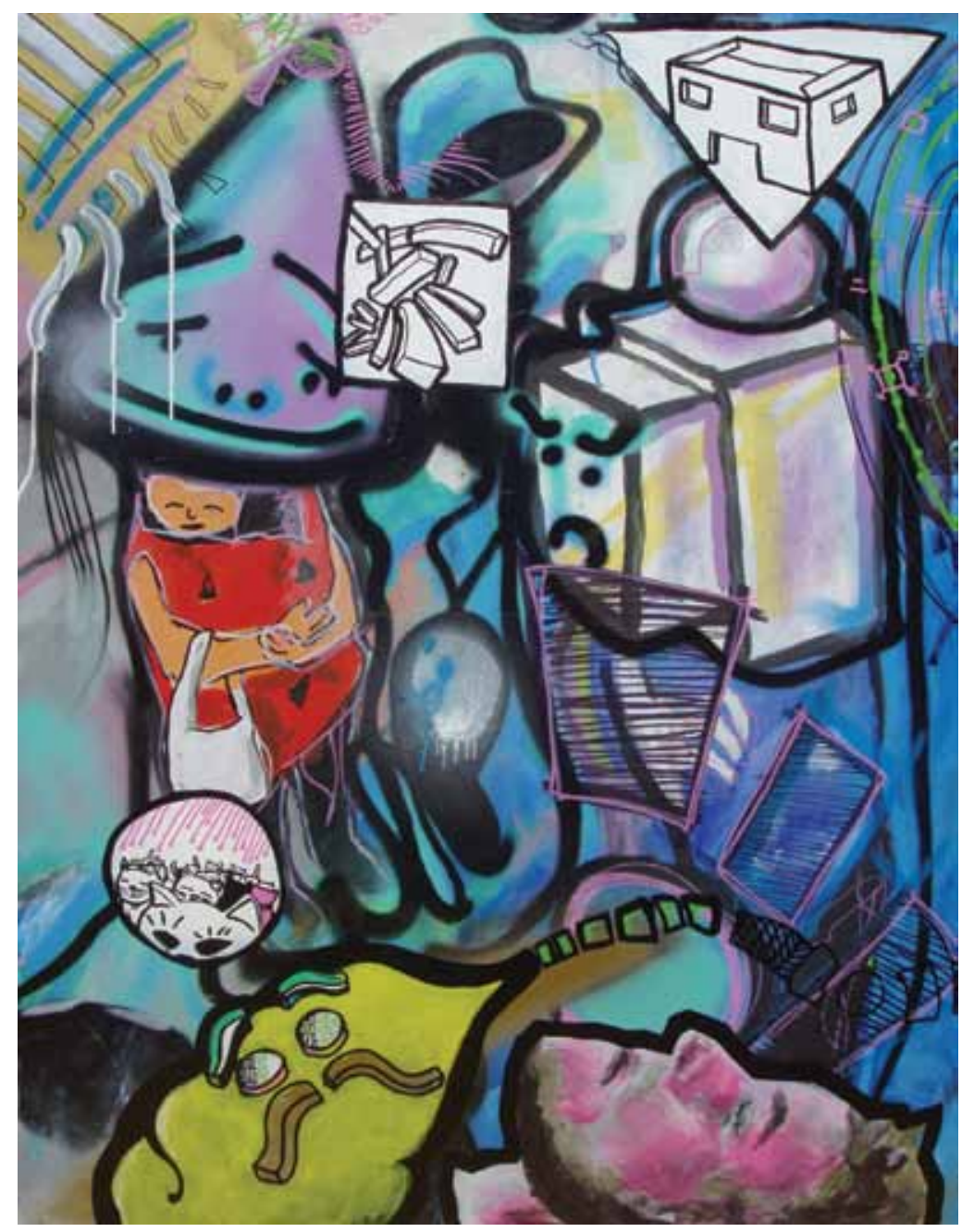

60 | Offset no. Io 